\title{
Rites of Passage: Special Reference to Ao-Naga Puberty Rites as Markers of Identity
}

\section{Dr. Resenmenla Longchar}

Assistant Professor, Department of History, ICFAI University, Nagaland.

Mail Id: resenmenlalongchar@iunagaland.edu.in

\begin{abstract}
Like in any other human society, in traditional Ao-Naga life, puberty is an important phase to be celebrated it as a rite. Ao-Nagas visualize puberty as an indicator to get married and ability to beget children through legitimate marriage. The celebration of puberty rites of the girls differ from person to person depending upon their respective physical appearances. The Ao-Naga society validates maturity more as a cultural construct than exclusively as a biological indicator. The process in AoNaga puberty rite includes several aspects to delineate the transit of the girl/boy from childhood to youth. Each aspect is unique and determines the identities of the individuals in their new thresholds as well as a member of the community. The process in Ao-Naga puberty rite includes several aspects to delineate the transit of the girl/boy from childhood to youth. Each aspect is unique and determines the identities of the individuals in their new thresholds as well as a member of the community. So this paper attempts to study the process of the puberty rites of the Ao-Naga boys and girls separately. And also, Van Gennep's theoretical approach to 'rites of passage' is applied in my case study to analyze how Ao-Nagas construct their own self and also as a member of the community.
\end{abstract}

Keywords: Puberty, Rites of Passage, Identity, Threshold

\section{Introduction}

Like in any other human society, attainment of the age of puberty is the state wherein the girl/boy shifts their status and roles from childhood to youth. Likewise, even in the traditional Ao Naga life puberty is an important phase to be celebrated as a rite and visualize puberty as an indicator to get married and ability to beget children through legitimate marriage and so forth. The ritual practices with regard to puberty are not time-bound as in other communities. The entire process continues till the girl or boy biologically, psychologically, and culturally becomes fit to get married and beget children and establish a healthy family. In the Ao Naga community, the puberty rites of 
the boys are not as elaborate as that of girls. For boy's attainment of puberty indicate a state at which they can launch for the activities meant for men like war tactics, construction of the house, art and craft, and so forth. Unlike other tribal societies in India ${ }^{1}$, Ao-Nagas give less or no ritual importance to the first menstrual blood as a marker of identity for puberty and often hide the matter from publicity but begins from the time once the girl develops her secondary sexual characters. Among the Ao-Nagas, rites of puberty are communally celebrated which means that the girls of the village who are more or less of the same age group or who appear to be reaching puberty stage are grouped and begin the communal celebration of the ritual. The Ao-Naga society validates maturity more as a cultural construct than exclusively as a biological indicator.

The process in Ao-Naga puberty rite includes several aspects to delineate the transit of the girl/boy from childhood to youth. Each aspect is unique and determines the identities of the individuals in their new thresholds as well as a member of the community. So this paper attempts to study the process of the puberty rites of the Ao-Naga boys and girls separately. And also, Van Gennep's theoretical approach to 'rites of passage' is applied in my case study to analyze how AoNagas construct their own self and also as a member of the community.

Arnold Van Gennep (1960) holds that the rite of passage rituals mark significant transitions in human lives, such as birth, puberty, marriage, and death. To him, the rite of passage means any ritual that escorts the passage from one status to another and from one world, whether cosmic/social, to another. The idea of significant passage rituals was first introduced by Gennep, who saw rebirth as the law of life and described rites of passage as a threefold process: rites of separation; rites of transition (liminality from the Latin, limen, meaning threshold); and rites of incorporation. The individual would first be ritually removed from the society as a whole, then he would be isolated for a period, and finally, he would be incorporated back into the tribe in his new status.

\section{Puberty rites of girls}

Incorporating Gennep's threefold process of rites of passage i.e., rites of separation; rites of transition and rites of incorporation we will first discuss the process of the Puberty rites of girls. There are five steps that complete the process of puberty ritual.

\section{The phase of tattooing (teptsii atep)}

Tattooing is the major determinant of identity for the Ao girls for it symbolizes the beginning of

\footnotetext{
${ }^{1}$ Gonds and Todas tribal girl undergo rites during her onset of menstrual cycle (Singh and K.S. B.V.Bhanu._People of India: Maharashtra Part 1. Mumbai, Popular Prakashan, 2004, p.687).

"Life Cycle rituals." http://ietd.inflibnet.ac.in/bitstream/10603/814/12/12 chapter\%205.pdf. Accessed 27 March 2011.
} 
the process of puberty, the stage at which they can claim for membership in their community. Tattooing rite is a long process. Basing on the tattooing ritual the rest of the puberty rites are followed and preformed accordingly. As cited above, the puberty rite of the girls doesn't begin with the starting of the menstruation. But onset of puberty is indicated through ritual act, teptsü atep (tattooing) ${ }^{2}$ done on different parts of the body in regular intervals over a period of five years, every year during the months of December and January which roughly correspond to the postharvest ${ }^{3}$ period. In these times the villagers enjoy leisure to relax by engaging themselves in proritual activities like tattooing the young girls and preparing them to the next phase of life. Further, the Ao-Nagas feel that since the environment during the season is so pleasant that it would heal up the wounds on the skin due to tattooing. The community thus maintains harmony with the nature to construct their cultural identities.

Each act of tattooing is followed by a period of rest that is, freeing from other domestic activities. The entire process of tattooing has five times tattooing and five times rest. Tattooing is an important practice in the community since these marks on body of the girls denotes not only their membership in the community but distinguishes them from the 'slaves' who according to the customary law are banished from undergoing the process. The people are scared that the evil spirits and animals like tiger would kill the girls who are not protected by tattooing. The community believes that those who are not tattooed would have less chances of getting good matches. For the girls to remain unmarried brings disgrace to them in the society. Such beliefs with regard to tattooing are very much deep-rooted in their worldview.

The general age to begin the ritual of tattooing is between years of 10 to 14 depending on the physique. Every year all the girls of the same age in the village are tattooed in the same season. The girls are separated from the society and are excluded from attending any community feast and family sacrifices, domestic and agricultural works during the occasion of tattooing because it is a cautious and sanctified period for those who are undergoing the rite of tattooing. Till the sores were healed she is allowed to have only rice, bamboo pickle and water. During tattooing all food prohibited to her like any animal meat were avoided. Till her wounds are healed she remains in the process period. Once a girl undergoes her first year's tattoo she is regarded as a full-fledged member of the community.

\subsection{Art of tattooing}

Tattooing is a specialized craft and art designed and executed by specialists from the community. In Ao-Naga society, only old women who have expertise chose the profession of tattooing. It is a

\footnotetext{
${ }^{2}$ Sangtem Naga girls are tattooed on the arms, calf, forehead and chin but the boy were not tattooed (Ganguli, Milada. $A$ Pilgrimage to the Nagas. New Delhi, Oxford \& IBH Publishing Co., 1984, pic.22). The Phoms tattoo their women only on the legs, but an Ao woman could be tattooed anywhere from face downward to the legs.

${ }^{3}$ The people were active in art and craft works like basket making, weaving etc for them to use for the next year.
} 
hereditary profession following in the female line. The expert mother trains their daughters, who in turn train their successors. In the past, it was more or less mandatory for a daughter of a tattooist to follow her mother's profession. It is because they believed that if the profession is not practiced by the successors, the art would soon disappear and make them poor and disgraceful.

Tattooing is executed in a jungle adjacent to the village. Before initiating tattooing upon a girl, a fowl has to be sacrificed to appease any evil spirit that might cause pain during the process of tattooing. Since the tattooing rite is gender-specific activity for woman, the entry of men is strictly prohibited. Nagas believe that the presence of men on the spot would not only increase the pain but also affects the design of the tattooing. People apprehend that the breath (amu) of the men will affect the health of the girl. Even though the girls know that tattooing causes much pain and suffering, and sometimes even death. However, it was compulsory for all the girls to get tattooed on their bodies (Smith 22).

\subsection{Tattooing instruments: Colour}

In the traditional Ao-Naga society, the colours used for tattooing were made from the juice of the bark of a tree, Ngupti or 'Naptti'. The technology was primitive. The bark of the tree is rubbed back and forth against a flat stone slab with rough surface. Then the juice of the bark is collected by hand into a pot boiled on firewood. Rice beer was added to the juice after it was half-boiled. Sharp cane thorns fixed to a wooden holder was used to apply the colour to the design on the skin. The pattern to be tattooed was marked by an old woman on the girl's skin with a piece of wood dipped in the colouring liquid. The piercing was done by gentle hammering on the implement into the skin. Root of kamri tree was used as a needle to pierce. After the first round of piercing is done, the colour (Nap) is then applied once more after the blood has been washed off.

\subsection{Designs of the tattoo}

Different designs of tattooing were placed on different parts of the body of the girls.

In the first year, the legs up to the calves were tattooed because, generally, the girls were not allowed to tattoo on their bodies before they attain puberty. In the second year, chest, chin, shoulder were tattooed. In the third year, the patterns of the calves were finished and lastly, in the fifth year, the tattooing completes with wrists and stomach.

The pattern varied slightly from Mongsen and Chungli group ${ }^{4}$ of the Ao-Naga. But generally, there are four vertical lines on the chin, a chain of lozenges from the throat to the bottom of the breast bone, inverted letter ' $\mathrm{V}$ ' shape on the front of the shoulders and stomach, lozenges and sides squares on the wrests, lozenges on the lower part of the leg, and a sign of arrow pattern on the knee (Mills 30). After the wounds of the tattooing were healed and dry skin

${ }^{4}$ Mongsen and Chungli are two distinctive dialectic groups. 
was peeled off, the grace of the designs appear.

\section{The phase of hair growth on the head}

The girls in pre-puberty stage in traditional societies do not maintain big hairs on the head. The head was frequently shaven indicating their childhood. The girls were allowed to grow hair permanently on the head till they can tuft it in a form. This process accompanies tattooing. The Naga women dress their hair in the form of a bun, Lemlangvi/Kapok. The girls from Mongsen and Chungli sects of Ao-Naga had different hair dressing styles. The Mongsen wears white in colour while the Chungli wears black in colour which was made of fallen hair that had been collected. The community believes that the Mongsen first invented the use of yarn, so they use the hair bun round with string made of white thread. The traditional Ao-Naga society emphasizes much care on hair care of girls. It is held that Ao-Naga boys adore the long shiny hair of the girls. Because the society believes that, the girls with such hair would have graceful married life.

\section{Sobusolemtsu, ritual clothing}

Once the girl underwent first tattooing, the next mark of her entry into youth is tying of a cloth, often-dark blue or white in colour. The cloth is tied on the waist of the body covering breasts and lower pelvis. The cloth used to tie is called tokojentsü. Then süpiti/teperemsü, skirt which is wrapped around the waist is started to wear once she enters into Tsüki, girls' dormitory. All the clan is visibly distinguished by their varied clothes and ornaments. The dress of married and unmarried girls differs. The young girls wore bodice which is just a piece of shawl to cover her breast. Until she becomes a mother, her breasts were not exposed. As women's clothing is concern; wife and daughter were depended on the husband/father richness. Whose father/husband had done Mithun ${ }^{5}$ sacrifice wears a different pattern on her skirt and besides clothing; they wear crystals earrings, brass rings, hornbill feathers, brass bracelets which clearly indicate that they belong to the rich and wealthy family. Poor and ordinary women were not entitled to wear such ceremonial clothes even during festivals.

\section{Piercing of upper earlobes (Narongto)}

Piercing of holes in the upper earlobes, narongto and insertion of ear ornaments Yongmen in them is another sign that symbolizes the process of puberty rite. Yongmen is a brass ear ornament. It is like a thrice coiled of ring of about nearly four inches diameter and half inch thickness. An old woman with a sharp pointed bamboo stick or a red-heated iron does the piercing. Once the wound was heal, one end of the coiled rod was press in both the upper hole of the earlobe and it is turn slowly and slowly until the whole ring is put in the ear holes. These two big brass rings are tied together across the head by a bunch of black threads to keep the hair intact. It is done during

${ }^{5}$ The Mithun (Bos Frontails) exist both in wild and semi-domesticated form. This animal has religious significance and intimate relation with socio-cultural life of the people. 
the first year of tattooing. During this process, the parents strictly make the girls to observe the rules of purity and pollution like eating animal's meat, avoiding any community feast and family sacrifices, domestic and agricultural works till the wounds of the ears are completely healed. Among the Ao-Nagas some clans' like Pongen, Jamir are not entitled to wear this ear ornament Yongmen. Hence they need not pierce the upper earlobes. It shows that the girl has attained marriageable age and is capable of bearing children.

\section{Entering into the girls' dormitory (Tsüki)}

Tsüki can be defined as girls' dormitory wherein the young unmarried girls were kept under the guardianship of an old woman called Tsükibutsüla/matron. Usually the home of the oldest women of the clan (Tsükibutsüla/matron) is chosen as a residence for the five to seven young girls in the village. There were several dormitories in every location (mepu/khel) because every clan has their own respective Tsüki as the Ao practice clan exogamy.

The young girl is allowed to sleep in the corner of the house. As a neophyte, new entrant she must do minor domestic works that furnishes her the knowledge of housekeeping and management. The girl should reach the dormitory earlier than her senior members and should take care of the domestic needs like collecting of firewood, igniting up of fire, fetching of water, pounding of paddy, cooking, sweeping, feeding of pigs and chicks and finally arranging the beds. She should even visit her parent's home to attend to the needs of her younger siblings and household chores. The dormitory training furnishes the requirements that a typical Naga maiden should possess in her real life. The girls are enlightened with the norms and values of the society and the duties of the people towards the family and society, customary law, etc. There are several folktales wherein the girls in the dormitory were imparted with such a knowledge system. Since the Ariju, boys' dormitory was organized separately on these lines there was a scope for the girls to choose their life partners in this context. The boys visit the girls' dormitory, but the girls cannot visit the boys' dormitory. In the same way, the young boys searching for partners respect the Tsükibutsüla and help her in manual works because she acts as the consultant or advisor. Till the girl gets married, she remains with her inmates in the dormitory under the supervision of Tsükibutsüla.

Only the eligible girls were entitled to become a member of this institution, once the girl goes through all the rites that are fixed by the community. After attaining puberty, the mother request and take permission from the Tsükibutsüla to allow her daughter to sleep in her house. After she attains her puberty if the parents continue to let the daughter sleep at their home it was a shameful part on them, so the custom made it compulsory for all the girls to sleep in the dormitory. After the request was granted, the girl's father prepares a bed (yipten) and sends it to the house of the Tsükibutsüla. The girl remains in the dormitory till she gets married. The ritual course of the Puberty rite is diagrammatically represented. 


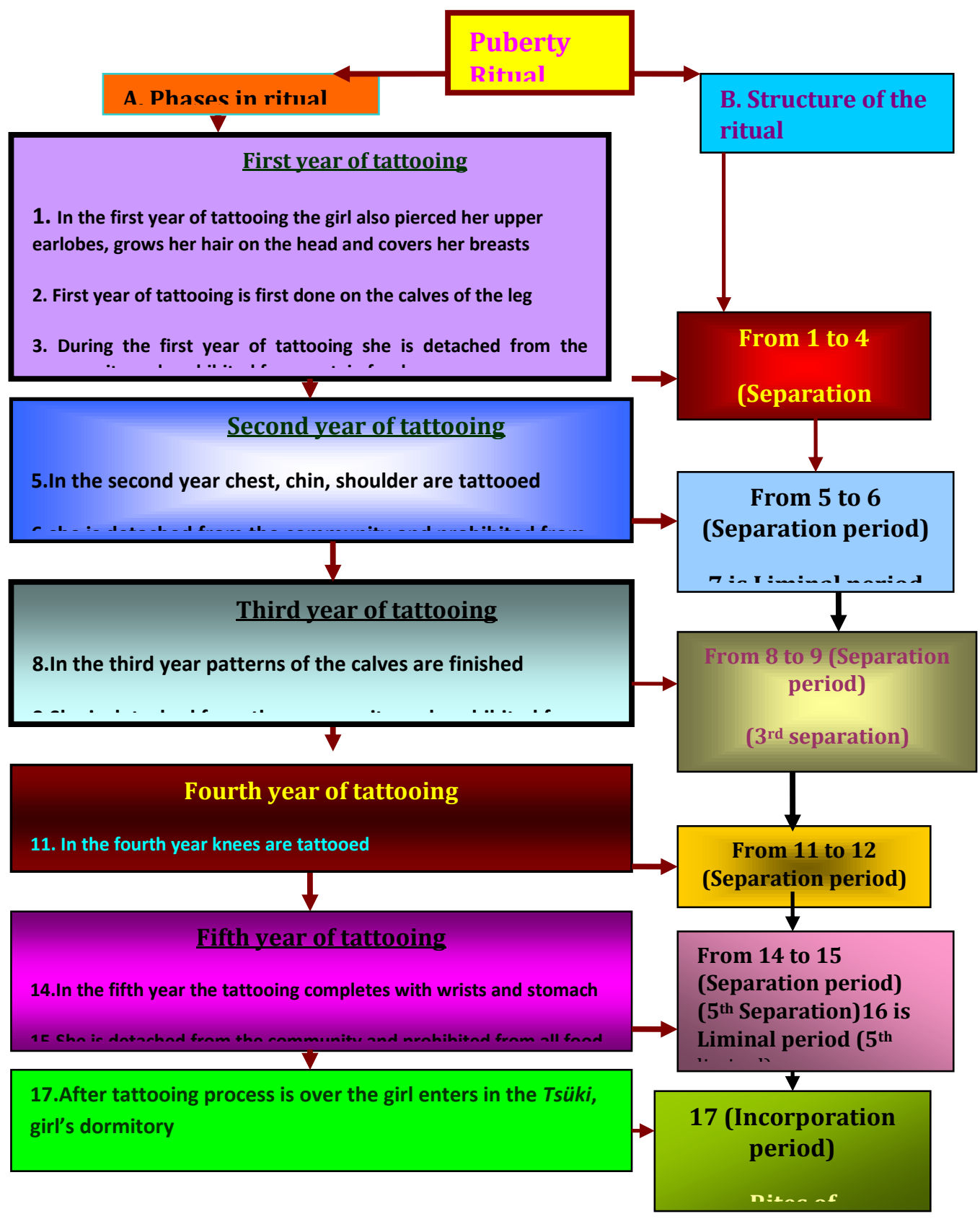

DIAGRAM NO.1: PUBERTY RITUAL OF THE GIRLS

Litinfinite Journal is Indexed By MLA Directory Of Periodicals \& MLA International Bibliography, EBSCO, ProQuest, SCILIT, Ulrichsweb \& Ulrich's Periodicals Directory, ICI World Of Journals, J-Gate, JISC-Sherpa Romeo, DRJI, EuroPub \& Other Major Indexing Services. (This Open Access article is published under a Creative Commons Attribution Non-Commercial 4.0 International License.) 


\section{Puberty rites of the boys}

In Ao-Naga society, the puberty rite for the boys is not as elaborate as that of the girls. For them, tattooing is not a marker of identity. Tattooing of men was closely associated with the practices of headhunting. It is a politico-religious rituals act that proves the prowess and masculinity of males. But every headhunter was not tattooed. A headhunter who brings the head of the enemy to home was tattooed.

In due course tattooing of men on this occasion was stopped. It is because the ritual process involved in tattooing done after head hunt required stringent practices, especially with regard to food to be observed by the ritual passenger. Sometime those observances became fatal for their lives. Hence keeping in view, the need of men to the society as sustainer these practices was discontinued. ${ }^{6}$ The puberty rites of the boys are divided into two stages, firstly ear-piercing rite and secondly rite of entering into Ariju. Under the Ariju system the boys complete the stages with three age group which the boys have to stay in each group for three years till they are promoted to the new age group.

\section{Piercing of upper earlobes (Narangto)}

Just like the girls, the boys also pierced their upper earlobes (narangto). The ear piercing was done just before the boy enters into the Ariju, boy's dormitory/Morung. It is performed by a male, either his relative or a friend. The ear is pierced using red-hot iron. When the iron is pushed through the earlobe, the dao blade is keep behind the ear to avoid injury to the head. This shows that he is ready to enter into adulthood.

\section{Entering of boys into the dormitory (Ariju)}

The boy enters into the Ariju (boys' or bachelors' dormitory). This institution was not just a simple place to sleep or for social gatherings, but it was a centre for socialization and an ideal learning institution. The Ariju serves the needs of society such as social security, promotion of culture and training centre of master artisanship. The man called tir who is also a religious head takes care of the male members. The entire life of Ariju was based on the age group system, züngaren. After joining the Ariju the boys become a member and responsible citizen to perform all sorts of community work enlisted to him or as group. Each age group has to remain in the same status for three years. The membership is extended to all the male members irrespective of their status as they are entitled into its system. The puberty phase of boys begins when they attain the age of 12 to 14 years and continue up to they get married. The phase completed with three stages. The

${ }^{6}$ Other Naga tribes in Nagaland like Chang, Khiamniungan and Konyak also practiced tattooing. See "Nagaland revisitedFrom Tuensang to Peren."http://www.pbase.com/neuenhofer/nagaland_revisited peren tuensang. Accessed 27 March 2011;

“India: Land of eternal Ink." http://www.vanishingtattoo.com/india tattoo history 4.htm. Accessed 27 March 2011. 
züngaren, age group is composed of three stages namely- Süngpur/tzüir age group, Tenapang age group and Chuzen age group.

\subsection{Süngpur/tzüir, first age group}

Süngpur/tzüir is the first and the junior most age group in the Ariju. The boys enter into Ariju at the age of 12 to 14 . He is separated from his parents partially and enter into Ariju to become Süngpur/tzüir. Süngpur means wood carrier and tzüir means water. Though the boys eat with their parents in their respective houses, but they sleep, learn and work in the Ariju. Every boy is accompanied by his father who brings an egg and keeps it on the ground to offer it as sacrifice. On entering the dormitory, he puts down the egg on the ground and prays to make his son to be strong, wise and flourish in all things as he stays in the dormitory. Some families sacrifice hen, rich families a pig or even a buffalo which is then used for the feasting of the Arijusanger (dormitory members). The parents invite relatives and friends and treat them with food and rice beer to mark the memorable occasions. Once the boy is inducted into the Ariju he is regarded as a full-fledged member of the village. They serve their seniors by doing menial works like collecting firewood, fetching water, sharpening of daos, massaging etc. The boys do all sorts of duties assigned to them by the seniors at anytime because they are under service training for three years. Failing to do their duties and test leads to severe punishment. Three years period is a time of vigorous training in order to discipline him and to prove that he is a worthy citizen to the society. The age of entry into Ariju earns their social status of man. The boy wears a shawl for one whole year and on the next year he wears langtem (apron) to show that he is eligible for marriage. A young Ao boy was given a dao holder and belt to wear at the age of five or six, before he gets hold of an actual dao, or other clothing. When the boy reached the age of fourteen or fifteen, cover his phallus with a small-netted carrier suspended from a string round the waist. Then he is permitted to carry the dao in his holder. This illustrates that the dao was the most basic masculine symbol within Ao society, as was also the case with most other Naga groups.

\subsection{Tenapang, second age group}

After three years of service and training as Süngpur/tzüir, the boys are promoted to the next age group called Tenapang, which means blooming period. This is a period where most of boys are ready to get married because they are entitled to marry. Most of the members marry and settled down at this period. Those who do not marry remain as Chuzen(the last age group) in the Ariju. Tenapang age group members do not so much menial duties like the younger age group but they abide by the rules and regulations of the Ariju. They continue to perform other works and duties under the supervision of Chuzen for upkeep and welfare of the Ariju. The Tenapang members' main duty is to teach the boys of the Süngpur/tzüir. 


\subsection{Chuzen, third age group}

The third age group is called Chuzen. This is the senior most group in the Ariju. They are considered as commanders of the Ariju and the most matured age group. They are the overall incharge of the activities of Ariju. The main duties of this group are building and repairing the Ariju, maintenance of the Ariju system and its organization, making decisions in the affairs of the Ariju administration and assigned duties to the respective Zünga (age group). They are the real bachelors of the village, almost free from all rules and disciplines but command respect and honour. The Ariju life retires at this age. Most of the men get married and settled independently. Any other member of outgoing Chuzen group who wish to remain as a member of Ariju remains as a member who is called sangremer, confirmed bachelor. But he cannot exercise his power as his group (Chuzen) is already succeeded by the younger group. The members who left Ariju after marriage and whose sons have not yet entered Ariju are called Arijusanger/arijununger. They always contribute their service and labour for common welfare of their Ariju. They no longer consider themselves as Arijusanger/arijununger after their sons enter the Ariju and ceased from all contribution to the Ariju. From this organization they are inducted into PutuMenden, village government.

\section{Boys Puberty ritual}

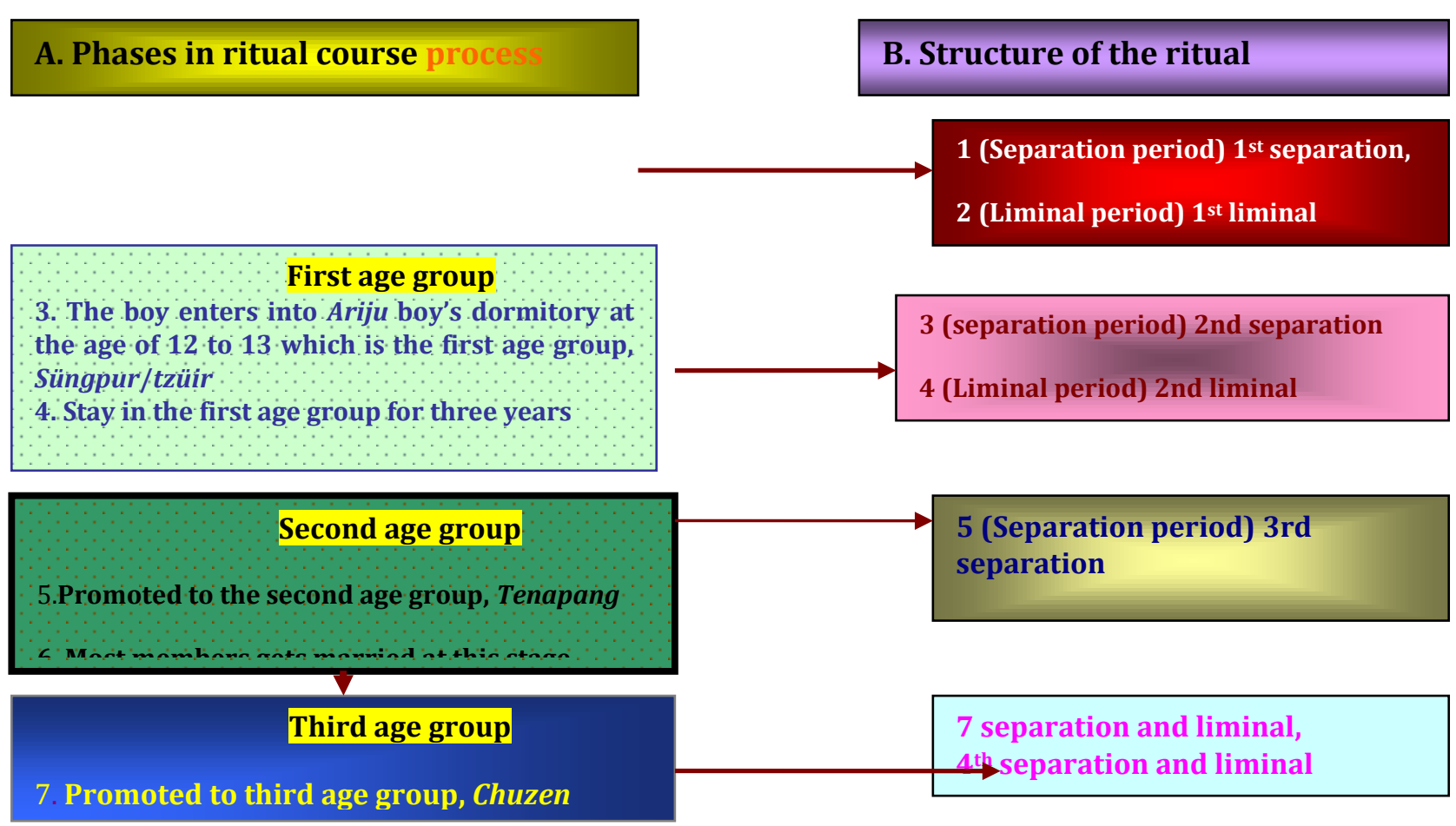

DIAGRAM NO. 2: BOYS PUBERTY RITUAL 


\section{Analysis}

The puberty ritual of the Ao-Nagas is represented (Diagram No. $1 \& 2$ ) in the (A) Phases in ritual course and (B) Structure of the ritual. The above diagram shows different steps of transition period of the girl and the boy from child to adulthood. The diagram also shows that the puberty stage is a very significant period where the boy and girl perform their fixed rites to construct their own self and also as a member of the community.

The boy's dormitory played an important role in bringing up great warrior among the Ao men. All the war tactics and special training and testing were given to the boys in the Ariju. The young men were energized by the pressure of rivalry among peers and hence they had to prove their worth by taking heads in succession. Regarded as a prelude to marriage, each Ao young man usually hoped to take one head at least. A man who had taken a head has more advantages. For marriage, it enhances his status and adorn with war medals, a means to enhance his personality, and to avoid the scorn of others. Ao young men were supposed to be competent in the game of feuding and raiding but the 'quick one' with the ability to lead his warriors and track down enemies was celebrated in ritual, story, songs and oratory. He was the 'sushir' or commander of the contingent. The sushir was selected for one battle but a good sushir was appointed again if he proved his worth and if he was willing to retain the title. Selection was done by the village rulers on behalf of the whole village community. The sushir gets sandwiched between two pressures, to lead his contingent towards success and to retain his position as commander.

The puberty stage is a very significant period where the boy and girl perform their fixed rites to construct their own self and also as a member of the community. Puberty rites of the AoNaga boys and girls are different. The girls' puberty rites are more elaborate than the boys. The tattooing rite of the girl is the symbol for constructing identity because it is the major rite performed for a longer period during puberty ritual. The girl pierced her upper earlobes (narangto), starts to grow her hair on the head, and covers her chest once the tattooing starts. The onset of the menstrual blood of the girl is not celebrated among the Ao-Naga because it is not inbuilt in the culture rather it becomes an individual thing or personal matter.

Unlike the other tribes of India7, the separation and the liminality are continuous, and they merged together. In puberty rites of the girls, separation and liminality occurs five times (B) Structure of the ritual. In the first year of tattooing (1 to 4$)$, the girl is separated from the societal activities like community feast and family sacrifices, domestic and agricultural works and abstains from all food prohibited to her. Till her wounds of the tattooing are healed she is in liminal period.

\footnotetext{
${ }^{7}$ Among the Kolams tribe, the girl/boy who go through the puberty rituals are considered as adults during incorporation period. See Rao,K.Mohan. The Kolams a primitive tribe in Transition. Hyderabad, Booklinks Corporation, 1990, pp. 119-128.
} 
Again, in the second, third, fourth and fifth year of tattooing (5 to 16) again separation and liminality continued. Separation alongside is followed by liminality because she is in process of entering into another stage called adulthood from childhood. The tattooing procedure is same all these years, but the girls are tattooed in different part of the body every year. Unlike the theoretical model of liminality put forward by Victor Turner ${ }^{8}$, in the Ao-Naga puberty ritual the boy and the girl is not in the state of betwixt or between and neither here nor there because the boy and the girl gets his/her status/identity during the liminal period itself. Before she even enters into the puberty (adulthood) stage, the rites of teptsü atep (tattooing) on the first year itself made her a full-fledged member of the community and shows that she has reached the marriageable age. Even the boy obtains his identity through the piercing of earlobes before entering into the dormitory (B) Structural of the ritual, rites of separation (1). He also becomes a full-fledged member of the village once he enters into the dormitory.

Tattooing was very significant because tattooing gives one's identity in the Ao society regarding to which clan and group she belongs. Tattooing was fairly common among the Naga tribes. Tattooing was the preparatory rites to enter into the puberty stage. Once the tattooing starts, the remaining puberty ritual follows one after the other. Irrespective of the fact that tattoos were used to differentiate status or for purposes of identity, it was compulsory for all Ao women and the fact that there was universal admiration among the Ao for such a practice shows that it was a rite of passage. ${ }^{9}$ The role of tattoos was not only part of the identity but more importantly it contributed to the self-image of the Ao-Naga women. The Chungli and Mongsen women have their own distinctive tattoo pattern which was significant for identification. It differentiates their group by their tattoo. Most importantly it helps the boys to identify the girls to which group she belong especially when the time comes to look for a partner. The Chungli women bear's three parallel black lines vertically on the chin, crisscross lines on the chest, on the leg below the knee but three lines horizontally at the calves. But the Mongsen women differ by a crisscross line at the backside of the leg. The traditional practices of tattooing are now taboo due to the influence of Christianity.

Once the girl undergoes or completes all the puberty rites, she then incorporated into the Tsüki, girls' dormitory. She is legitimized by incorporating into the dormitory (B) Structural model (17). This signifies that she is capable for marriage. Unlike the girls, the boys enter into the Ariju/dormitory very early because they have the age group system (rites of incorporation (3 to 5). It is a very strict affair. The Tsükibutsüla/matron did not just simply permit a girl to enter the dormitory.

\footnotetext{
${ }^{8}$ Turner coined the term liminoid to refer to experiences that have characteristics of liminal experiences but are optional and do not involve a resolution of a personal crisis. According to him, the liminal/ liminoid entities are neither here nor there; they are 'betwixt and between' the positions assigned and arrayed by law, custom, convention, and ceremonial rite (Victor Turner, The Ritual Process: Structure and Anti-Structure, pp. 53-92, 95)

${ }^{9}$ M.Godden, Gertrude. "Naga and Other Frontier Tribes of North-East India." The Journal of the Anthropological Institute of Great Britain and Ireland, Vol. 26, 1897, pp. 161-201.
}

47

Litinfinite Journal is Indexed By MLA Directory Of Periodicals \& MLA International Bibliography, EBSCO, ProQuest, SCILIT, Ulrichsweb \& Ulrich's Periodicals Directory, ICI World Of Journals, J-Gate, JISC-Sherpa Romeo, DRJI, EuroPub \& Other Major Indexing Services. (This Open Access article is published under a Creative Commons Attribution Non-Commercial 4.0 International License.) 
Among the puberty rites of the boy's separation and liminality $(1$ to 5,7$)$ takes place for four times. When the ritual passenger enters into the dormitory for the first time, he is in separation period. He is separated from his house, bed and parents to another. For three years he is in liminal period because the passenger is in the process of entering into a new status. After three years is over, he is separated again from his old status to another one i.e., from his old age group to another new age group. During this period many boys marry and leave physically the dormitory. The one who gets married is incorporated into the society (6). After that he is again separated from the dormitory but promoted to the last age group. Those remains unmarried is again separated and remains in liminal period when he is in the last age group.

\section{Conclusion}

To conclude, from the diagrams we can see that in the puberty rituals, the rites of separation and incorporation are simple and less time-consuming whereas the rites of liminality are more and elaborate. It may be because the community finds the liminality as a period of relaxation from routine than a period of confusion. They perceive the period of liminality as a site of preparation and training for proceeding to the next stage. In general, in the Ao Naga rites of passage, the separation and incorporation rites are simple whereas the liminal period is long. The traditional puberty rites of the Ao-Nagas seem to be simple but the rituals from transition to maturity take years. The puberty rites are significant for the Ao-Nagas because it sends signals that the child has reached the age of responsibility, fertility and, community productivity. Before reaching maturity, the rites allow them to go through defacement such as tattooing, piercing of earlobes and they also go through tests of endurance such as pains, seclusion from family and society. The puberty rites help them to be a responsible member of society and clearly defining the social responsibility and obligations between adults and non-adults. In contemporary time, the traditional practices of puberty rites are no longer observed because of the influence of Christianity. The only way to keep the identity of the puberty rite is through the narratives of the community, photographs, and through attires. 


\section{References}

Douglas, Mary. Purity and Danger: An analysis of the concepts of pollution and taboo. London: Ark Paperbacks, 1975. Print.

Gennep, Arnold Van. The Rites of Passage. Chicago: University of Chicago Press, 1960. Print.

Hutton, J. H. Angami Nagas. London: Direction of the Assam Administration Macmillan and co., limited, 1921. Print

Imchen, Panger. Ancient Ao Naga Religion and Culture. New Delhi: Har Anand Publication, 1993. Print.

Jamir, N.Talitemjen \& Lanunungsang, A. Naga Society and Culture- A case study of the Ao Naga Society and cultures. Nagaland: Nagaland University Tribal Research Centre. 2007. Print.

M.Godden, Gertrude. "Naga and Other Frontier Tribes of North-East India", The Journal of the Anthropological Institute of Great Britain and Ireland, Vol. 26 (1897), pp. 161-201.

Mills, J.P. The Ao-Nagas. Oxford : Oxford University Press, 1926. Print.

Smith, W.C. The Ao-Naga Tribes of Assam. New Delhi: Mittal Publications, 2002. Print.

Turner, Victor. The Forest of Symbols: Aspects of Ndembu Ritual. New York: Cornell University Press, 1967. Print.

Turner, Victor. The Ritual Process: Structure and Anti-Structure. New York: Routledge, 1969. Print.

Dr.Resenmenla Longchar finished her PhD from Centre for Folk Culture Studies, Hyderabad Central University. Presently she is the Head of Department, Department of History, ICFAI University Nagaland and Secretary of Research Board, ICFAI University Nagaland. Her area of interest are oral histories and folk traditions, community studies, northeastern Indian tribal cultures and sustenance patterns, folk narrative research, contemporary discourses on research trends and prospects, folk religion, rituals, gender and identities, political ideologies and institutions in tribal societies and customary law, material culture and socio-economic formations. 